\title{
ANALYSIS OF FACTORS INFLUENCING DURABILITY OF FERROCONCRETE ENGINEERING CONSTRUCTIONS EXPOSED TO CORROSION DAMAGES
}

\author{
Ekaterina Gennadievna Pakhomova ${ }^{1 *}$ Anna Alekseevna Dorodnykh ${ }^{1}$ Mikhail lgorevich Loktionov ${ }^{1}$ \\ ${ }^{1}$ Southwest State University, Kursk, Russia
}

This work is dedicated to researches of durability of engineering constructions ferroconcrete exposed to synergistic influence of corrosion damages and having concrete and working reinforcement damages.

Key words: Durability, Ferroconcrete designs, Corrosion damages, Engineering constructions

\section{INTRODUCTION}

Technological and constructional demands shall be ensured in course of providing the serviceability of ferroconcrete engineering constructions. One of the most important issues of prolongation of serviceability of buildings and engineering constructions is their protection from the impact of a corrosive environment.

One of the main reasons for forming a corrosion in ferroconcrete constructions is the impact of aggressive environments of anthropogenic and natural occurrences. It leads to active destructive processes. It is also well known that changes of properties of the material with time depends on its interaction with the environment and has an irreversible nature. The most spectacular examples are seen in areas of running levels of water and active chemical and physical impact of the environment. For example in constructions of industrial hydraulic engineering (hyperbolic cooler towers, vent cooling towers, aeration tanks, settling filters, docks cameras, gravity quays). During exploitation period of 6-8 years depth of concrete corrosion reaches the level of 8-10 centimetres and for the period of 25-30 years it might reach the level of 1-1,5 meters. Besides, as the aggressive environment penetrates the body of the construction protective properties of concrete in relation to a reinforcement decrease and it starts to corrode. It all influences the carrying capability of ferroconcrete construction [01].

\section{RESEARCHES OF THE PROCESS OF CONCRETE CORROSION UNDER THE IMPACT OF DIFFERENT ENVIRONMENTS}

Examination of corrosion of ferroconcrete might show a synergistic impact as a complex interaction of the environment (high humidity, temperature, etc.), aggressive environments (various liquids, gases, solid aggressive formations) with consideration for stress strain behaviour of a ferroconcrete element [02].

Synergistic impact of environments leads to significant changes of stress strain behaviour of a concrete in the affected area. Changes of properties of a material with time have irreversible nature and depend on deformation conditions and interaction with the environment. Besides, as the aggressive environment penetrates the body of the construction protective properties of concrete in relation to a reinforcement decrease and it starts to corrode. As the result of the corrosion the cross section square of a reinforced construction and its coupling with the concrete decrease. It all influences the carrying capability of ferroconcrete construction.

Damages of a concrete are noted after impact of water solutions, acids or acid gases, salt solutions and even caustics some types of organic compounds. Aggressive impact degree is determined not only by its contents but also by conditions of contact, velocity and pressure of liquids, density of adjacent ground during groundwater action, temperature of the environment, power load, pressurized state of a material of constructions and other factors.

In fact all the impacts that include aggressive solid matters and gases may be referred to the synergistic as the presence of the water is necessary for chemical reaction in normal conditions.

All the gases impact concrete constructions with participation of $\mathrm{CO}_{2}$. In majority of cases advancing process is carbonization of a concrete which starts from the moment of manufacturing of a construction whereas specific acid gases as the rule start to act only after beginning of exploitation of a building. Impact of gases on a concrete induces its neutralization and forming salts penetrates with a speed depending on their solubility, permeability and humidity of a concrete. Nature of basic destructive processes is presented in the Table 1.

\section{ESTIMATION OF CORROSIVE CONCRETE DAMAGE}

To estimate corrosive concrete damage in ferroconcrete engineering constructions owe might use the following factors: depth of a concrete damage and service life.

The final cause for formulation of the mathematical model of corrosion $L=f(t)$ is acquiring the simple formula which makes engineering calculations more comfortable. 
Table 1: Typical cases of interaction of a construction with the environment

\begin{tabular}{|c|c|c|}
\hline Environment & $\begin{array}{c}\text { Conditions of impacts } \\
\text { of the environment }\end{array}$ & $\begin{array}{c}\text { Prevailing } \\
\text { processes in a concrete }\end{array}$ \\
\hline Aero-aquatic & $\begin{array}{c}\text { Non-ramming } \\
\text { Pressure }\end{array}$ & $\begin{array}{c}\text { Neutralization } \\
\text { The same, accelerated }\end{array}$ \\
\hline $\begin{array}{c}\text { Aero-aquatic, with the } \\
\text { presence of salt solutions, } \\
\text { acids, etc and with peri- } \\
\text { odic humidification }\end{array}$ & $\begin{array}{c}\text { Non-ramming } \\
\text { Pressure }\end{array}$ & $\begin{array}{c}\text { Increase of number of aggressive components and products } \\
\text { after interaction with a concrete stone, neutralization, } \\
\text { diffusion of aggressive ions }\end{array}$ \\
\hline $\begin{array}{c}\text { Water with the presence } \\
\text { of salt solutions, acids,etc }\end{array}$ & $\begin{array}{c}\text { Non-ramming } \\
\text { Pressure }\end{array}$ & $\begin{array}{c}\text { Diffusion of aggressive ions } \\
\text { Same + disalinizing }\end{array}$ \\
\hline
\end{tabular}

Table 2: Characteristic of synergistic interaction of two matters

\begin{tabular}{|c|c|c|c|}
\hline $\begin{array}{l}\text { Examples of interaction } \\
\text { of a concrete with a } \\
\text { diffuse environment }\end{array}$ & Description of a process & $\begin{array}{l}\text { Differential equation, describing } \\
\text { the process [2] }\end{array}$ & \\
\hline $\begin{array}{l}\text { Contact of a concrete } \\
\text { stone with salt solu- } \\
\text { tions, acids, etc. }\end{array}$ & $\begin{array}{l}\text { Presence of chemical interaction } \\
\text { of a concrete with the environ- } \\
\text { ment, process is controlled by the } \\
\text { diffuse and chemical reactions }\end{array}$ & $\left.\begin{array}{c}\frac{\partial C_{A}}{\partial t}=D_{A} \cdot \frac{\partial^{2} C_{A}}{\partial x^{2}}+R C_{i} \\
\frac{\partial C_{B}}{\partial t}=D_{B} \cdot \frac{\partial^{2} C_{i}}{\partial x^{2}}+\frac{K_{B} S_{B}}{\Pi_{B}} R\left(C_{i}\right)\end{array}\right\}$ & 1) \\
\hline $\begin{array}{l}\text { Contact of a concrete } \\
\text { stone with chlorides }\end{array}$ & $\begin{array}{l}\text { Absence of chemical interaction } \\
\text { of a concrete with the environ- } \\
\text { ment, process is controlled by the } \\
\text { diffuse and chemical reactions }\end{array}$ & $\frac{\partial c_{A}}{\partial t}=D_{A} \cdot \frac{\partial^{2} C_{A}}{\partial x^{2}}$ & 2) \\
\hline
\end{tabular}

However, practically all the researchers making $L=f(t)$ dependency take into account only two matters interaction As the result of methodical approach to the determination of service life of a concrete and preparation of suggestions on the quantitive evaluation of kinetics of corrosive processes appearing during the contact of liquid aggressive environments with a concrete which were based on the analysis of the nature of corrosive processes in works of native authors the following conclusions are made [01]:

- It was established that the intensity of corrosive processes is determined by the intensity of penetration of aggressive components of the environment to the pore structure of a concrete;

- movement of the aggressive environment from the external surface deep inside a concrete is conducted under the hydrostatic pressure, molecular diffusion and capillarity; pressure of the environment on an open surface of a concrete accelerates this process:

- such classification of interacting forces, inducing the movement of the aggressive environment in a concrete lets perform quantitive calculations for the stationary conditions of a stream of an aggressive matter through a surface of a concrete and evaluate its influence on a concrete's condition during simple boundary conditions.
Corrosion of a concrete in an item or a construction is induced by actions of organisms. Biological corrosion in majority of cases appears in constructions where a surface of ferroconcrete meets organic matter. Corrosive destruction is accompanied by disalinizing of calcium and magnesium as a sulphate from a concrete [03].

Climate impacts on a concrete among which are temperature, air humidity, number of transfers through $0{ }^{\circ} \mathrm{C}$, destroy a surface structure of its layers, lead to formation of enclosed micro cracks which connect each other and form perforated pore system making access for further impacts of ions and carbon dioxide easier.

General theory of processes taking place during frost penetration of a water saturated concrete is now in development stage. Special features of a destruction process during frost penetration of a water saturated concrete were described in works of V.M. Moskvin, V.B. Gusev, N.K. Rozental and other authors. Movement of frost penetration level and increase of a volume during phase transfer into an ice induces transfer of the water. Herewith pore pressure increases that decreases the crystallization temperature. If there are salt solutions in the water its temperature also depends on concentration of these salt solutions [04]. 


\section{CONCLUSIONS}

Examination practice shows that one of the main reasons for decrease of carrying capability of ferroconcrete constructions is impact of aggressive environment. The most negative result of such an impact is chemical corrosion of ferroconcrete. In industrially developed countries damages form the corrosion evaluated in $3 . .5 \%$ from a gross national level, and $13 . . .19 \%$ are fall to share of engineering structures. At the moment the impact of corrosion on a carrying capacity of ferroconcrete constructions is estimated approximately.

Level of aggression of the environment and depth of destruction of a surface layer of a concrete, influencing the decrease in a carrying capacity of ferroconcrete constructions are presented in the Table 3.

Table 3: Loss of a carrying capacity due to exploitation of a construction

\begin{tabular}{|c|c|c|c|}
\hline \multirow{2}{*}{$\begin{array}{l}\text { Level of } \\
\text { aggression } \\
\text { of the envi- } \\
\text { ronment }\end{array}$} & \multirow{2}{*}{$\begin{array}{l}\text { Depth of } \\
\text { destruction } \\
\text { of a surface } \\
\text { layer, } \\
\text { mm/year }\end{array}$} & \multicolumn{2}{|c|}{$\begin{array}{c}\text { Annual average loss of } \\
\text { a carrying capacity due to } \\
\text { exploitation of a } \\
\text { construction, } \%\end{array}$} \\
\hline & & underground & $\begin{array}{l}\text { carrying } \\
\text { and } \\
\text { bordering }\end{array}$ \\
\hline Weak & Up to 0.4 & 3 & 5 \\
\hline Medium & $0.4 \ldots 1.2$ & 5 & 10 \\
\hline Strong & $\begin{array}{c}\text { More than } \\
1.2\end{array}$ & 8 & 15 \\
\hline
\end{tabular}

Level of aggression of the environment influencing the depth of damage of reinfirced construction is presented in the Table 4.

Table 4: Level of aggression of the environment

\begin{tabular}{|c|c|c|c|}
\hline $\begin{array}{c}\text { Level of } \\
\text { the enviression of } \\
\text { ment }\end{array}$ & $\begin{array}{c}\text { Corrosion } \\
\text { damages, } \\
\text { mm/year }\end{array}$ & $\begin{array}{c}\text { Points in } \\
\text { accordance } \\
\text { with GOST } \\
13819-68\end{array}$ & $\begin{array}{c}\text { Decrease } \\
\text { of durabil- } \\
\text { ity in the } \\
\text { corrosion } \\
\text { area, } \%\end{array}$ \\
\hline Non-aggressive & 0.1 & $1 \ldots 3$ & 0 \\
\hline Weak & $0.01-0.05$ & 4.5 & Up to 5 \\
\hline Medium & $0.05-0.5$ & 6 & Up to 10 \\
\hline Strong & $>0.5$ & $>7$ & $>10$ \\
\hline
\end{tabular}

The evaluation of service life of a construction is made in accordance with Equation 1:

$$
t_{\text {mp }}=t_{06} \delta^{2} /\left(m_{1} \cdot x_{06}\right)^{2}-t_{\text {об }}
$$

Where $t_{\circ \sigma} ; t_{\text {пр }}$ are correspondingly term of exploitation of a construction to the moment of examination and anticipated term of exploitation (service life); $x_{0 \sigma}$ - the depth of carbonization of concrete to the moment of the research.

Durability of concretes is enhanced by increasing the quantity of a cement, quality contraction, however it doesn't prevent its damage and destructions in aggressive environments. Destruction of a defensive layer of a concrete is aroused by acid gases, chloride, carbon dioxide which activate the carbonization process.

Concrete's humidity is the factor that makes aggressive salts and gases chemically active in a cement. As the result processes of disalinizing of calcium hydroxide as a consequence of its hydrolysis, formation of salts from lime, cement, acids or acid solutions are initiated what followed with destruction of a concrete [05].

\section{REFERENCES}

1. В.М. Москвин, Ф.М. Иванов, С.Н. Алексеев, Е.А. Гузеев. Коррозия бетона и железобетона. Методы их защиты. М.: Стройиздат.1980 г.-536 с.

2. Пахомова Е.Г., Горбунова И.Н. Работоспособность железобетонныхконструкцийприсинергетических воздействиях агрессивных сред / Известия ЮгоЗападного государственного университета. Серия: Техника и технологии. 2012. - № 2-2. - С. 125-127.

3. Биоповреждения в строительстве / Под ред. Ф.М. Иванова, С.Н. Горшина.-М.: Стройиздат.1984

4. Пухонто Л.М. Долговечность железобетонных конструкций инженерных сооружений: (силосов, бункеров, резервуаров, водонапорных башен, водонапорных стен). Монография. - М.: Изд-во АСВ, 2004 -424 стр. с илл.

5. Durable Concrete Structures. CEB Design Guide, №182. Thomes Telford, 1992, 128 pp. 